\title{
Assessment of Pollution and Improvement Measure of Water Quality Parameters using Scenarios Modeling for Sungai Selangor Basin
}

(Penilaian Pencemaran dan Peningkatan Ukuran Parameter Kualiti Air menggunakan

Pemodelan Senario untuk Lembangan Sungai Selangor)

\author{
MD. SADEK UDDIN CHOWDHURY, FARIDAH OTHMAN*, WAN ZURINA WAN JAAFAR, \\ NUZAIMA CHE MOOD \& MD. IBRAHIM ADHAM
}

\begin{abstract}
Sungai Selangor is very important from the viewpoint of water supply and multipurpose water use in Malaysia. The water quality of this river is degrading due to point and non-point sources of pollution. This study, focus on the water quality assessment and simulation the effect of the pollution sources from urbanization to the Sungai Selangor basin. Water quality Index (WQI) is used to define the status of river water quality and the QUAL2K was used as a simulation model. Water quality parameters $\mathrm{DO}, \mathrm{BOD}$ and $\mathrm{NH}_{3}-\mathrm{N}$ have been chosen for modeling. In addition, five different model scenarios were simulated to observe the impacts of pollution sources on the Sungai Selangor water quality. WQI results showed that most of the stations in this river basin recorded water inferior to Class III. The water quality model presented different scenarios for changes of Sungai Selangor water quality. Simulation results for different scenarios showed that reduced levels of $\mathrm{BOD}$ and $\mathrm{NH}_{3}-\mathrm{N}$ at $51.10 \%$ and $66.18 \%$, respectively, can be obtained if Scenario-5 is employed. The river water quality issue in the Rawang sub-basin within the study area is considered crucial to create significant improvement within the sub basin and in the downstream area of Sungai Selangor basin.
\end{abstract}

Keywords: Scenarios modeling; Sungai Selangor; water quality

ABSTRAK

Sungai Selangor adalah sumber penting daripada sudut bekalan air dan pelbagai guna di Malaysia. Kualiti air bagi sungai ini semakin merosot disebabkan oleh pencemaran punca titik dan bukan titik. Kajian ini tertumpu kepada penilaian kualiti air dan simulasi kesan punca pencemaran dari kawasan membangun kepada lembangan Sungai Selangor. Indeks Kualiti Air (WQI) telah digunakan untuk menilai status kualiti air sungai dan QUAL2K digunakan untuk simulasi permodelan. Tambahan pula, pelbagai senario model telah disimulasi bagi memerhatikan kesan kepada punca pencemaran terhadap kualiti air Sungai Selangor. Keputusan WQI menunjukkan bahawa kebanyakan stesen di lembangan sungai ini berada dalam Kelas III. Model kualiti air menunjukkan bahawa pengurangan BOD dan $\mathrm{NH}_{3}-\mathrm{N}$ sebanyak $51.10 \%$ and $66.18 \%$ boleh dicapai sekiranya Senario-5 diguna pakai. Isu kualiti air sungai di sub-lembangan Rawang adalah dianggap penting bagi penambahbaikan di dalam sub-lembangan dan kawasan hilir lembangan Sungai Selangor.

Kata kunci: Kualiti air; pemodelan senario; Sungai Selangor

\section{INTRODUCTION}

Rivers are the main sources of fresh water for all human activities (Hema \& Subramani 2013). Rivers at their source are unpolluted, but as water flow downstream, the river is receiving point and non-point pollutant sources, resulting in negative impacts on river water quality. The degradation of water resources has increased the need for determining the ambient status of water quality, in order to provide an indication of changes induced by anthropogenic activities. The surface water resources are being polluted due to urbanization, increased industrial activities, intensive farming and over use of fertilizers in agricultural productions, discharge of untreated waste water and sewage outlets (Dhanalekshmy et al. 2014). In order to control source pollution and improve water quality, it is important to know the spatiotemporal characteristics of organic contaminant concentrations in affected receiving waters (Wang et al. 2015). River water quality can be assessed either with a few, select important water quality parameters or individual parameters (Ibrahim et al. 2015). Based on the use of standard parameters for water classification the Water Quality Index (WQI) has been considered one of the possible criteria for river water classifications. The WQI represents the level of water quality, which is a numeric expression, used to transform large quantities of water categorization data into a single number (Bordalo et al. 2006; Sánchez et al. 2006;).

Sungai Selangor basin functions as the main source of water for the State of Selangor for domestic, industrial and irrigation purposes (Seyam \& Othman 2015). Approximately $60 \%$ of water consumption in Selangor and Kuala Lumpur is sourced from the Sungai Selangor 
(Subramaniam 2004). Rapid urbanization with increasing numbers of industries, STPs, wet markets, mining activities and agriculture have had a significant negative impact on Sungai Selangor's water quality and its associated ecosystems. Therefore, effective management of this river basin is of prime importance. In these consequences, water quality models have gained wide acceptance as a tool to predict the quality of water. Water quality modelling and simulation is rapidly becoming an integral part of environmental management. River water quality models are generally used to predict the water quality parameters along the river system reaches, resulting from the interactions of the physical, chemical and biological processes of oxygen demand. The model can be utilized to predict the effect of the available or proposed water quality control methods on water quality. Therefore, the water quality models can be used to assist watershed management decision-making in achieving the designated water quality objectives. QUAL2K (or Q2K) is a river and stream water quality model that is intended to represent a modernized version of the QUAL2E (or Q2E) model (Brown \& Barnwell 1987). US Environmental Protection Agency developed this model which considers the stream as a one-dimensional channel with the steady flow that is non-uniform and considers the influence of point source and non-point source pollution loads (Chapra et al. 2008). QUAL2K capable to simulate the migration and transformation of a wide variety of constituents including dissolved oxygen (DO), temperature, biochemical oxygen demand (BOD), chemical oxygen demand (COD), organic nitrogen, ammonia nitrogen $\left(\mathrm{NH}_{3}-\mathrm{N}\right)$, nitrate nitrogen $\left(\mathrm{NO}_{3}-\mathrm{N}\right)$, total nitrogen $(\mathrm{TN})$, sediment oxygen demand (SOD), organic phosphorus, inorganic phosphorus, total phosphorus (TP), phytoplankton and algae (Zhang et al. 2014). The illustrations and uses of this model are described in detail in the QUAL2K user's manual (Chapra et al. 2008). The QUAL2K model have been utilized in other areas for simulation of river water quality found throughout the literature (Bottino et al. 2010; Cho \& Sung 2010; Fan et al. 2009; Kannel et al. 2007; Marzouni et al. 2014; Moalla et al. 2013; Park \& Yong 2002; Vasudevan et al. 2011; Zhang et al. 2014, 2012). The effect of pollution from the industrial area to Sungai Tebrau, Malaysia using QUAL2K model has been investigated and concluded (Zainudin et al. 2010), that at the downstream of the river, the industrial discharge was the major contributor of the pollutant. Most recently, QUAL2K has been applied to simulate the water quality and analyse the effect of improving the water quality in different watershed around the world (Dylan 2016; Kim et al. 2016; Sunusi et al. 2016; Zhang et al. 2016).

Evidently, the contamination of the Sungai Selangor basin has been continuously increasing during the last decade due to the increment of urban activities, industrial activities, agricultural activities and commercial activities, and residential areas. However no study has been carried out so far on water quality model for a dominantly agricultural and forest land use. Thus in this study, we apply QUAL2K to Sungai Selangor which provides a clear understanding on the control of point sources to maintain a reasonable water quality class at the downstream of the Sungai Selangor. This will assist decision makers to identify the spatial levels and reasons for water quality problems, such as land use practices and their effects on the water body of the Sungai Selangor Basin. Furthermore, the outcomes of the research can provide a benchmark level to be used in the exploration of strategies to protect human health and the ecosystem and an environmental reference for water pollution control of the Sungai Selangor basin. The objective of this study was to evaluate the improvement of point and non-point sources pollution created by countermeasures using QUAL2K of Sungai Selangor basin. First, WQI was calculated based on one year water quality data and classified the water quality according to National Water Quality Standard (NWQS) for Malaysian rivers. Second, the QUAL2K model was applied to calibrate and validate the hydraulic and water quality parameters of Sungai Selangor. Finally, a variety of scenarios were simulated using the calibrated QUAL2K model.

\section{MATERIALS AND METHODS}

\section{STUDY AREA}

Sungai Selangor basin is located within the state of Selangor, Malaysia (Figure 1). The catchment area is about $2200 \mathrm{~km}^{2}$; nearly a quarter of the total area of the State of Selangor. The basin is located to the north of Kuala Lumpur City, bounded by the Klang basin in the south and Bernam basin in the north and encompasses the districts of Gombak, Kuala Selangor and Hulu Selangor. Sungai Selangor flows in a south-westerly direction and traverses a total distance of about $110 \mathrm{~km}$ before discharging into the Straits of Malacca. Sungai Selangor is recognized as the largest source of water for the states of Selangor and Kuala Lumpur. The main tributaries are Batang Kali, Serendah, Buloh, Kerling, Sembah, Kundang and Rawang. The rainy season, i.e. the North Monsoon, usually runs from October to April and the dry season, i.e. the South Monsoon, is from May to September (Malaysia's and Climate 2016). The basin is divided into 10 sub-basins based on hydrological boundaries.

\section{SAMPLING}

Eleven sampling stations were selected throughout Sungai Selangor basin. Sampling was carried out from October 2013 to September 2014. The chemical and physical variables of the river were measured directly at each sampling station. These include temperature, DO, electric conductivity (EC), pH and turbidity. The equipment was calibrated prior to use based on the manufacturer's directions. All the samples collected from the field were kept in cool room at a temperature below $4^{\circ} \mathrm{C}$ to reduce all the activities and metabolism of the organisms in the water. $\mathrm{BOD}_{5}$, $\mathrm{COD}$, SS and $\mathrm{NH}_{3}-\mathrm{N}$ were analyzed in the laboratory according to the standard methods (APHA 2003). 


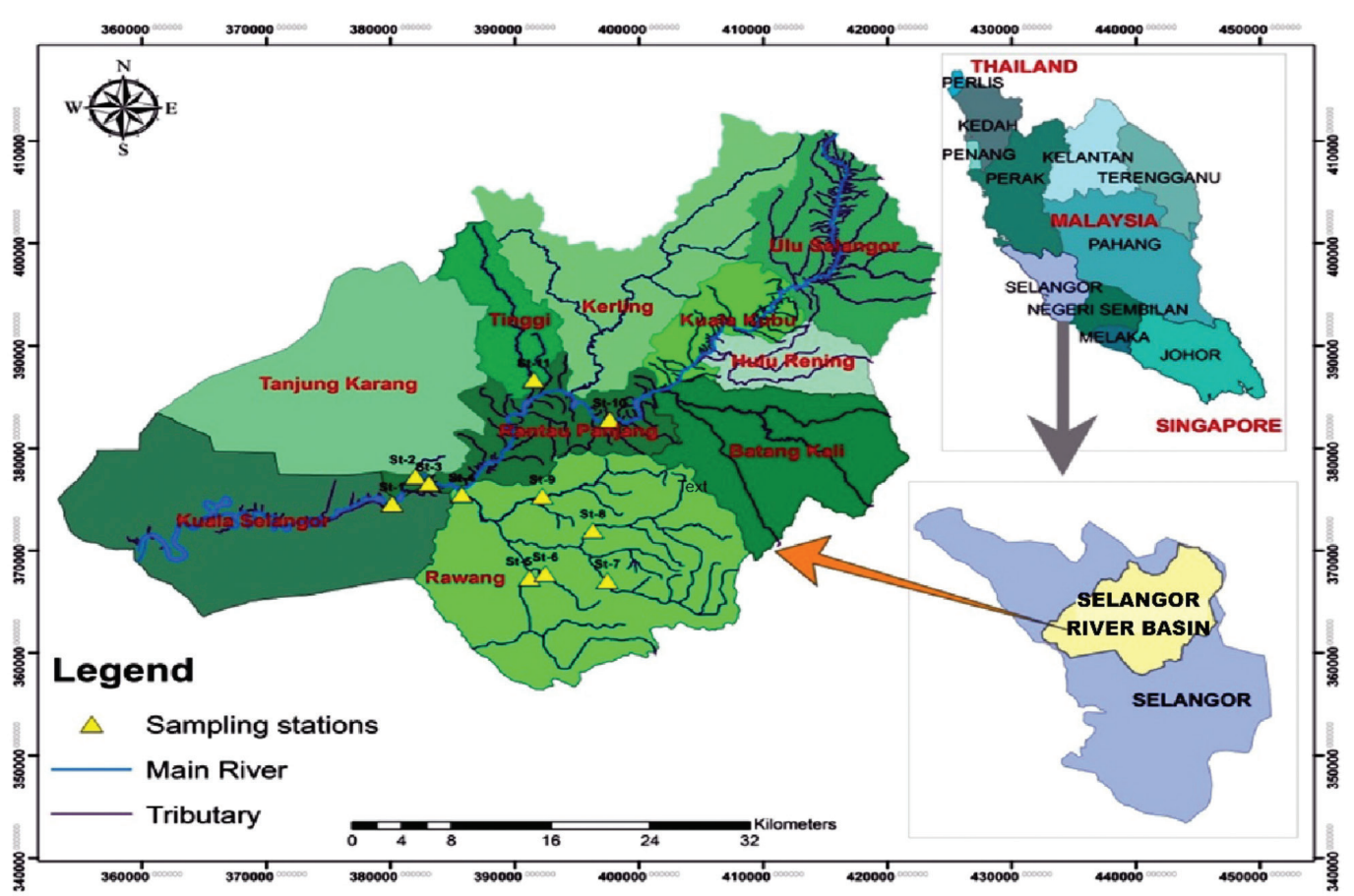

FIGURE 1. Location map of Sungai Selangor Basin with sub-basins and sampling stations

\section{WATER QUALITY INDEX (WQI)}

Pollution level of river water quality assessment was conducted by calculated WQI. The water quality index was obtained with the following equation (DOE 2009) is given by (1),

$$
\begin{aligned}
\mathrm{WQI}= & 0.22 \mathrm{SIDO}+0.19 \mathrm{SIBOD}+0.16 \mathrm{SICOD} \\
& +0.16 \mathrm{SISS}+0.15 \mathrm{SINH}_{3}-\mathrm{N}+0.12 \mathrm{SIpH}
\end{aligned}
$$

where WQI is the water quality index; SIDO is the sub-index of DO; SIBOD is the sub-index of BOD; SICOD is the subindex of COD; $\mathrm{SINH}_{3}-\mathrm{N}$ is the sub-index of $\mathrm{NH}_{3}-\mathrm{N}$; SISS is the sub-index of TSS; and $\mathrm{SIpH}$ is the sub-index of $\mathrm{pH}$. The sub-indices of all parameters were calculated based on sub-index calculation table given by DOE, Malaysia (DOE 2009).
RIVER WATER CLASSIFICATION AND CRITERIA

There are five classes of water quality classification based on WQI value. The ranges of classes are shown in Table 1 while class definitions are shown in Table 2.

\section{MODEL SETUP AND DATA INPUT}

The steps sequence of developing the water quality model by QUAL2K illustrates in Figure 2. Sungai Selangor has been divided into 13 reaches with 6 junctions to accommodate all the sub-basins and the river tributaries within the Selangor sub-basin. Figure 3 shows the schematic diagram of Sungai Selangor basin represents the reaches, junction system, sampling station and head water. The upstream border is just after Selangor Dam, while the downstream border is limited to $15 \mathrm{~km}$ upstream from the coastal region.

The model allows several water quality parameters to be input in accordance with data availability as well

TABLE 1. Thresholds class limit of WQI and its parameters (DOE Malaysia)

\begin{tabular}{lcccccc}
\hline \multirow{2}{*}{ Parameter } & UNIT & \multicolumn{5}{c}{ Class } \\
\cline { 3 - 6 } & & $\mathrm{I}$ & $\mathrm{II}$ & $\mathrm{III}$ & $\mathrm{IV}$ & $\mathrm{V}$ \\
\hline $\mathrm{NH}_{3}-\mathrm{N}$ & $\mathrm{mg} / \mathrm{L}$ & $<0.1$ & $0.1-0.3$ & $0.3-0.9$ & $0.9-2.7$ & $>2.7$ \\
$\mathrm{BOD}$ & $\mathrm{mg} / \mathrm{L}$ & $<1$ & $1-3$ & $3-6$ & $6-12$ & $>12$ \\
$\mathrm{COD}$ & $\mathrm{mg} / \mathrm{L}$ & $<10$ & $10-25$ & $25-50$ & $50-100$ & $>100$ \\
$\mathrm{DO}$ & $\mathrm{mg} / \mathrm{L}$ & $>7$ & $5-7$ & $3-5$ & $1-3$ & $<1$ \\
$\mathrm{pH}$ & - & $>7$ & $6-7$ & $5-6$ & $<5$ & $>5$ \\
$\mathrm{SS}$ & $\mathrm{mg} / \mathrm{L}$ & $<25$ & $25-50$ & $50-150$ & $150-300$ & $>300$ \\
WQI & - & $>92.7$ & $76.5-92.7$ & $51.9-76.5$ & $31.0-51.9$ & $>31.0$ \\
\hline
\end{tabular}


TABLE 2. Water classes and uses (DOE Malaysia)

\begin{tabular}{ll}
\hline CLASS & USES \\
\hline Class I & $\begin{array}{l}\text { Conservation of natural environment. Water Supply I - Practically no treatment necessary. } \\
\text { Fishery I - Very sensitive aquatic species }\end{array}$ \\
Class IIA & Water Supply II - Conventional treatment. Fishery II - Sensitive aquatic species \\
Class IIB & Recreational use body contact \\
Class III & $\begin{array}{l}\text { Water Supply III - Extensive treatment required. Fishery III - Common, of economic value } \\
\text { and tolerant species; livestock drinking }\end{array}$ \\
Class IV & $\begin{array}{l}\text { Irrigation } \\
\text { Class V }\end{array}$ \\
\hline
\end{tabular}

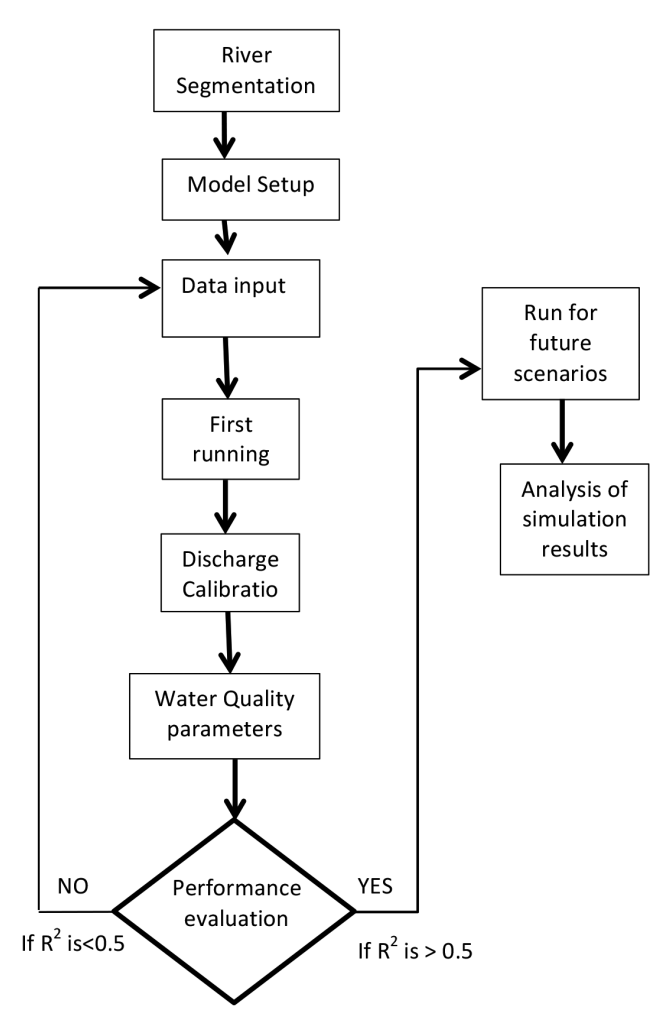

FIGURE 2. Model flow chart

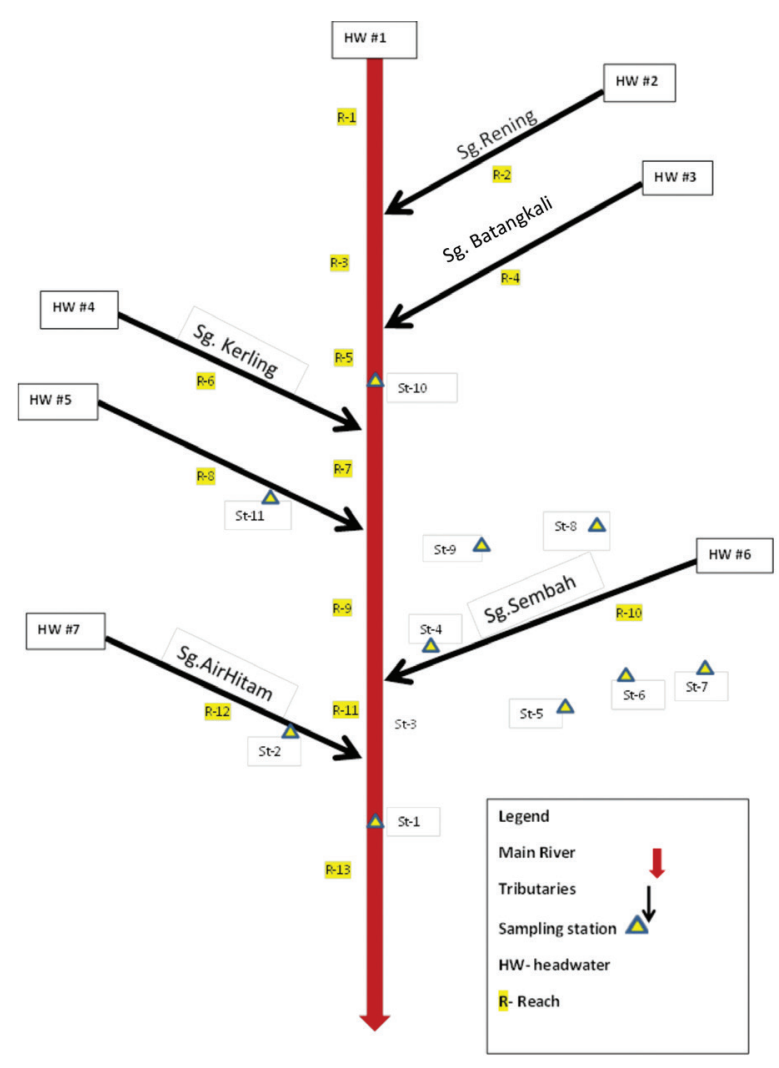

FIGURE 3. Schematic diagram of Sungai Selangor

PERFORMANCE EVALUATION CRITERIA OF MODEL

The $\mathrm{R}^{2}$ coefficient is the measure that shows how well the trends in the measured data are reproduced by the model simulated results. It provides the ratio of the variance of one variable that is predictable from other variable. The value of $\mathrm{R}^{2}$ range from 0 to $1\left(0 \leq \mathrm{R}^{2} \leq 1\right)$. The $\mathrm{R}^{2}$ for $\mathrm{n}$ number of measured and simulated data can be calculated using the following formula (2):

$$
R^{2}=\frac{\left(n \sum_{i}^{n} M_{i} * S_{i}-\sum_{i}^{n} M_{i} * \sum_{i}^{n} S_{i}\right)^{2}}{\left[n \sum_{i}^{n}\left(M_{i}\right)^{2}-\left(\sum_{i}^{n} M_{i}\right)^{2}\right] *\left[n \sum_{i}^{n}\left(S_{i}\right)^{2}-\left(\sum_{i}^{n} S_{i}\right)^{2}\right]}
$$


TABLE 3. Reach data of Sungai Selangor basin

\begin{tabular}{ccccccc}
\hline $\begin{array}{c}\text { Reach } \\
\text { No. }\end{array}$ & $\begin{array}{c}\text { HW } \\
\text { ID }\end{array}$ & $\begin{array}{c}\text { HW } \\
\text { Reach }\end{array}$ & $\begin{array}{c}\text { River } \\
\text { Name }\end{array}$ & $\begin{array}{c}\text { Length } \\
(\mathrm{km})\end{array}$ & $\begin{array}{c}\text { Upstream } \\
(\mathrm{km})\end{array}$ & $\begin{array}{c}\text { Downstream } \\
(\mathrm{km})\end{array}$ \\
\hline 1 & 1 & Yes & Selangor & 14.5 & 115.5 & 101.0 \\
2 & 2 & Yes & Rening & 21.0 & 21.0 & 0.00 \\
3 & 1 & & Selangor & 4.50 & 101.0 & 96.5 \\
4 & 3 & Yes & Batang Kali & 18.0 & 18.0 & 0.00 \\
5 & 1 & & Selangor & 13.0 & 96.5 & 83.5 \\
6 & 4 & Yes & Kerling & 11.0 & 11.0 & 0.00 \\
7 & 1 & & Selangor & 4.00 & 83.50 & 79.5 \\
8 & 5 & Yes & Sg. Buloh & 17.5 & 17.5 & 0.00 \\
9 & 1 & & Selangor & 14.5 & 79.5 & 65.0 \\
10 & 6 & Yes & Sembah & 24.5 & 24.5 & 0.00 \\
11 & 1 & & Selangor & 5.0 & 65.0 & 60.0 \\
12 & 7 & Yes & Air Hitam & 3.5 & 3.5 & 0.00 \\
13 & 1 & & Selangor & 60.0 & 60.0 & 0.00 \\
\hline
\end{tabular}

where $\mathrm{M}$ is the measure data, $\mathrm{S}$ is the simulated data and $\mathrm{n}$ is the number of the data points. According to to Henriksen et al. (2003), $R^{2}$ value of $\geq 0.85$ considered an excellent, between 0.65 and 0.85 considered very good, between 0.5 and 0.65 considered good, between 0.2 and 0.5 considered poor, while the values less than 0.2 considered very poor.

\section{SIMULATION METHOD OF SCENARIOS}

As an improvement measure, the calibrated model was applied to predict the effects on water quality; in particular the changes in DO, BOD and $\mathrm{NH}_{3}-\mathrm{N}$ level following the implementation of the recommended action plan. A number of scenarios were proposed and selected for the predictive scenario modelling. These scenarios are described in Table 4.

The water quality at the downstream of Sungai Selangor are degrading to the water quality standard of class-III, thus the simulation of predictive scenarios targeted to improve the water quality standard class-II. By simulating different scenarios, the load reduction rate of different scenarios was obtained such that the water quality at the end of Sungai Selangor reached the required standards. In the scenario SC-I, simulation input pollution concentrations of water quality parameters were adjusted to Standard A according to Malaysian Environmental Quality Act 1974 for all point sources located in the Rawang sub basin. In scenario SC-2, point sources pollution load within Rawang sub-basin was reduced by trial and error until the water quality simulation results met the water quality objectives. The SC-3 STPs are some of the main pollution sources at Rawang sub-basin. These sub-basin areas have not been served with centralized STP. Thus, in this simulation all STPs within Rawang sub basin were omitted with a central STP with compliance of Standard A located at the Sungai Serendah (Figure 4). The SC-4 demonstrates wetland performance on pollutant load and identifies the wetland effectiveness Wetland is one alternative for conservation practice not only for land management but also for water management. It is popular due to its effectiveness to reduce pollutant load with minimum maintenance and low cost. In this scenario two wet lands were considered at Sungai Rawang and Sungai Gontong (Figure 4). Scenario SC-5 is the combination of SC-1 and SC-4 that's construction of Wetland and Standard A compliance of all point sources within Rawang subbasin.

TABLE 4. Description of scenarios

\begin{tabular}{cl}
\hline Scenario & Description \\
\hline SC-1 & Standard A compliance of all point sources within the Rawang sub-basin \\
SC-2 & Reduction of point sources pollution load within the Rawang sub-basin \\
SC-3 & Installation of central STP with compliance of Standard A \\
SC-4 & Construction of Wetland within the Rawang sub-basin \\
SC-5 & Construction of Wetland and Standard A compliance of all point sources within the Rawang sub-basin \\
\hline
\end{tabular}




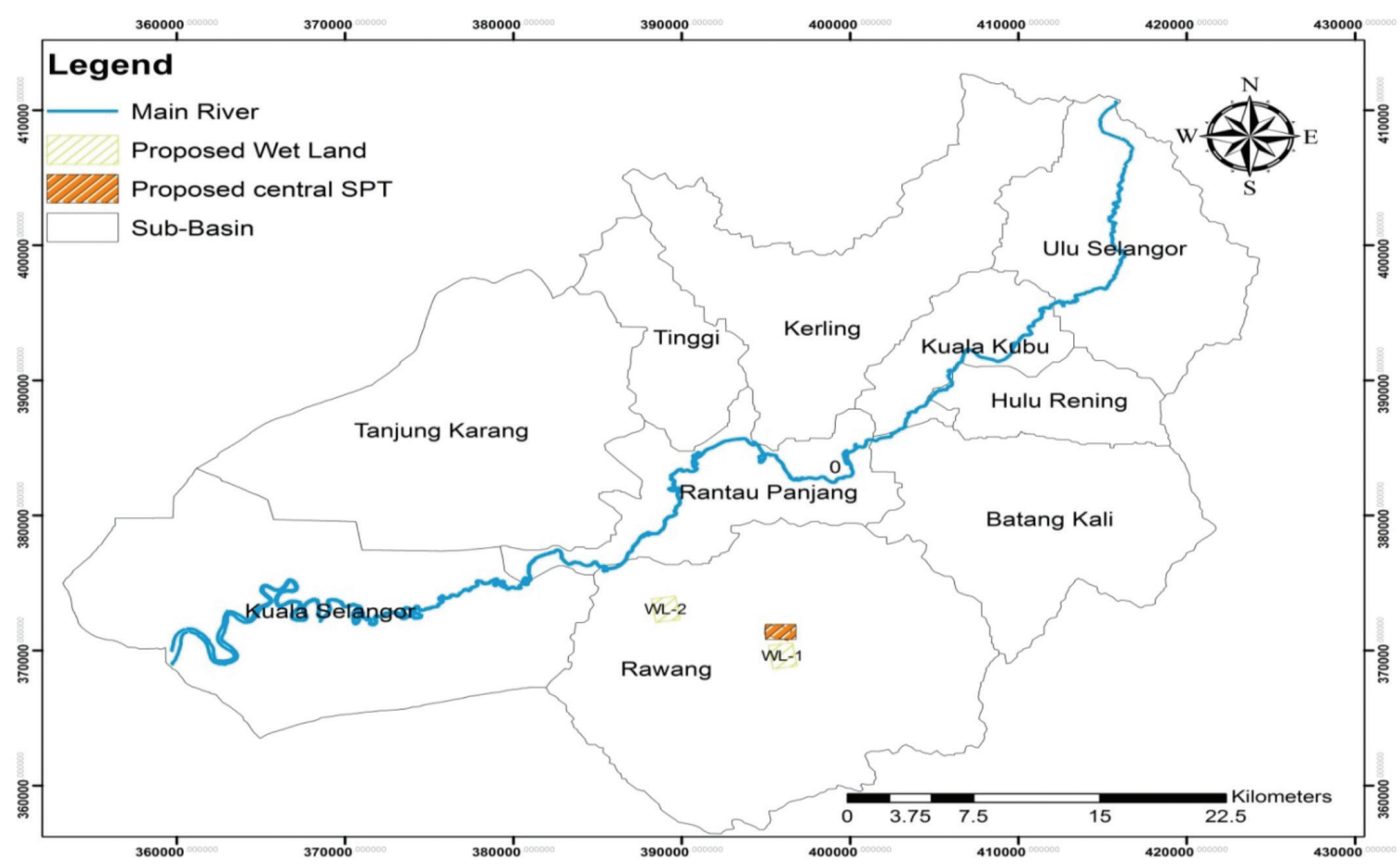

FIGURE 4. Location of proposed Wetlands and central STP

\section{RESULTS AND DISCUSSION}

\section{SAMPLING RESULTS}

The one year average water quality results are summarized in Table 5. The water quality result shows Sungai Selangor is affected in terms of high concentrations of BOD, COD and $\mathrm{NH}_{3}-\mathrm{N}$. The water quality of the Sungai Selangor varies from the upstream to the downstream region and it is also dependent on the different land use as been reported in the study at Bakun Reservoir (Teck et al. 2016). WQI results showed that sampling stations located at the upstream and middle stream registered Classes II, while in Rawang sub basin and downstream of Sungai Selangor, the water quality falls in class III based on the NWQS for Malaysian rivers. BOD, COD and $\mathrm{NH}_{3}-\mathrm{N}$ registered class-IV and $\mathrm{V}$ at some of the tributaries within Rawang sub-basin.

The WQI class variations according to point source and land use are visualized in Figure 5. Several more point sources are located in the Rawang sub-basin compared with the others sub-basins. The stations located in Rawang sub-basin receive wastewater from industries, STPs, food stalls and domestic effluents from unsewered areas. The degraded WQI can be linked with land use as seen in Figure 5. According to analysis, catchments with more forests

TABLE 5. Average water quality monitoring results

\begin{tabular}{cccccccc}
\hline Station & $\begin{array}{c}\mathrm{DO} \\
(\mathrm{mg} / \mathrm{L})\end{array}$ & $\begin{array}{c}\mathrm{pH} \\
(-)\end{array}$ & $\begin{array}{c}\mathrm{BOD} \\
(\mathrm{mg} / \mathrm{L})\end{array}$ & $\begin{array}{c}\mathrm{NH}_{3}-\mathrm{N} \\
(\mathrm{mg} / \mathrm{L})\end{array}$ & $\begin{array}{c}\mathrm{COD} \\
(\mathrm{mg} / \mathrm{L})\end{array}$ & $\begin{array}{c}\mathrm{SS} \\
(\mathrm{mg} / \mathrm{L})\end{array}$ & WQI \\
\hline St-1 & 5.43 & 6.58 & 3.69 & 0.50 & 21.7 & 117.5 & 79 \\
St-2 & 4.01 & 5.99 & 3.64 & 0.54 & 43.4 & 58.3 & 66 \\
St-3 & 5.06 & 6.68 & 4.36 & 0.88 & 18.3 & 122.8 & 76 \\
St-4 & 3.83 & 6.87 & 7.15 & 0.92 & 31.2 & 477.8 & 68 \\
St-5 & 3.22 & 6.88 & 6.73 & 1.74 & 29.4 & 374.7 & 69 \\
St-6 & 2.63 & 6.94 & 13.01 & 5.50 & 42.0 & 21.3 & 55 \\
St-7 & 4.66 & 7.24 & 6.57 & 1.38 & 50.8 & 137.6 & 71 \\
St-8 & 6.72 & 7.04 & 1.35 & 0.57 & 23.7 & 84.2 & 82 \\
St-9 & 5.83 & 6.79 & 5.13 & 1.88 & 33.2 & 304.2 & 70 \\
St-10 & 7.06 & 6.83 & 0.94 & 0.45 & 20.9 & 30.0 & 86 \\
St-11 & 6.32 & 6.17 & 1.44 & 0.54 & 22.6 & 13.2 & 81 \\
\hline
\end{tabular}




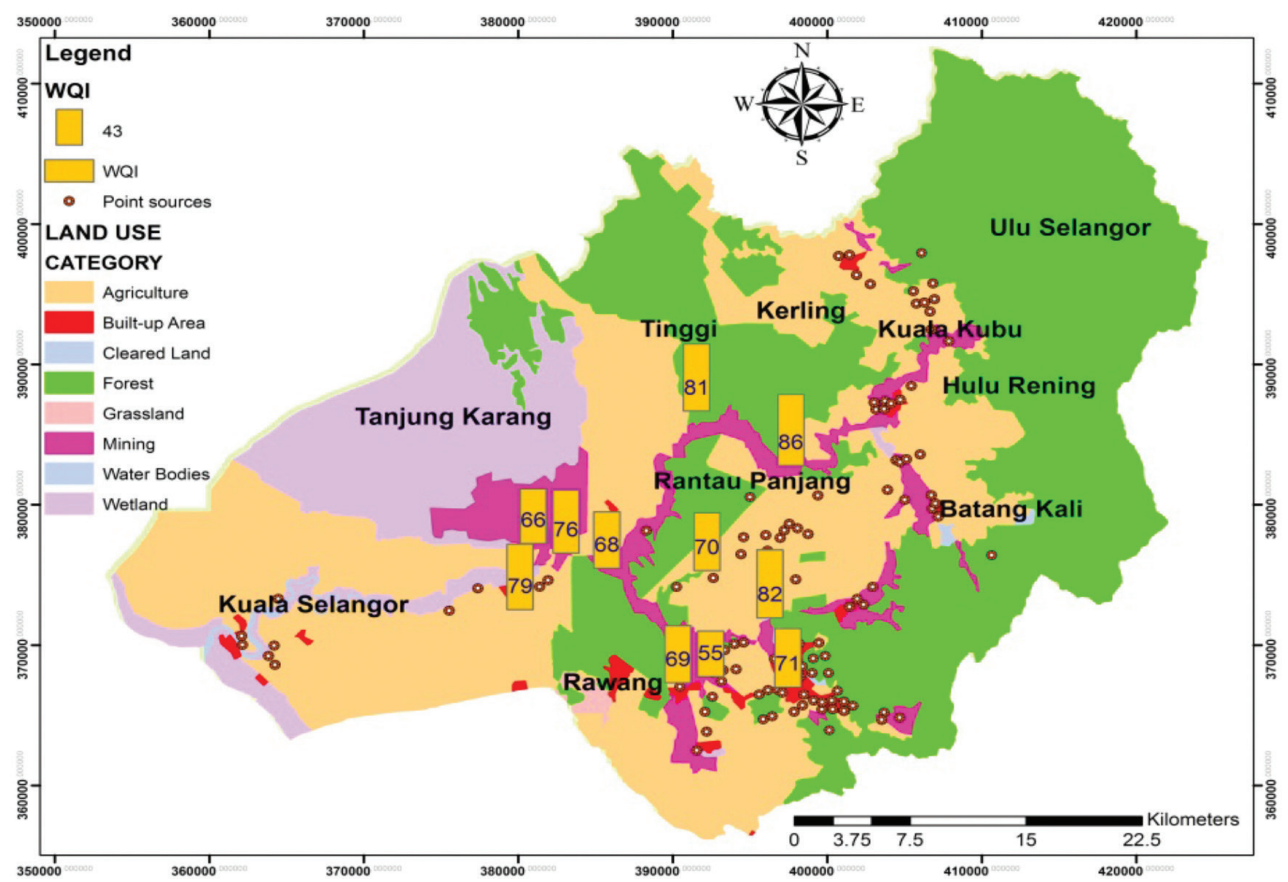

FIGURE 5. Land use, point sources and WQI along the Sungai Selangor basin

and less urbanization have better water quality. The water quality parameters (e.g. $\mathrm{NH}_{3}-\mathrm{N}, \mathrm{BOD}, \mathrm{COD}$ and $\mathrm{DO}$ ) had lower values in forested areas within Sungai Selangor basin. Forested land use generally acts as a nutrient detention zone as nutrients move downstream, which suggests strong biological nutrient retention (e.g. microbial and plant assimilation and microbial denitrification) (Gardner \& Brian 2009). In contrast, built-up land use was identified as the strongest contributor of $\mathrm{NH}_{3}-\mathrm{N}$, BOD and COD to Sungai Selangor basin, which may be highly influenced by point source as well as non-point sources of pollution. This is further supported by high concentrations of $\mathrm{NH}_{3}-\mathrm{N}(5.50 \mathrm{mg} / \mathrm{L})$ and BOD (13.01 $\mathrm{mg} / \mathrm{L}$ ) in urban-dominated rivers, which suggests chronic sewer leakage or illicit discharges (Paul \& Judy 2008). The analysis suggested that built-up land use and anthropogenic activities has a substantial impact on water quality in the study area (Suratman \& Norhayati 2013). About $80 \%$ of built-up areas are located in Rawang sub-basin, which is the most developed and a highly populated area within Sungai Selangor basin and where a lot of points and non-point sources are generated by industrialization and urbanization.

\section{RESULTS OF CALIBRATION AND VALIDATION OF THE MODEL}

\section{CALIBRATION OF DISCHARGE}

Figure 6 represents the comparison between the observed and simulated discharge for the main stream of Sungai Selangor. It shows that the pattern of observed discharge is similar to that of the simulated discharge. As shown in Figure 6, the correlation between the observed and simulated discharge $\mathrm{R}^{2}$ is 0.9934 which can be considered excellent according to Henriksen et al. (2003).
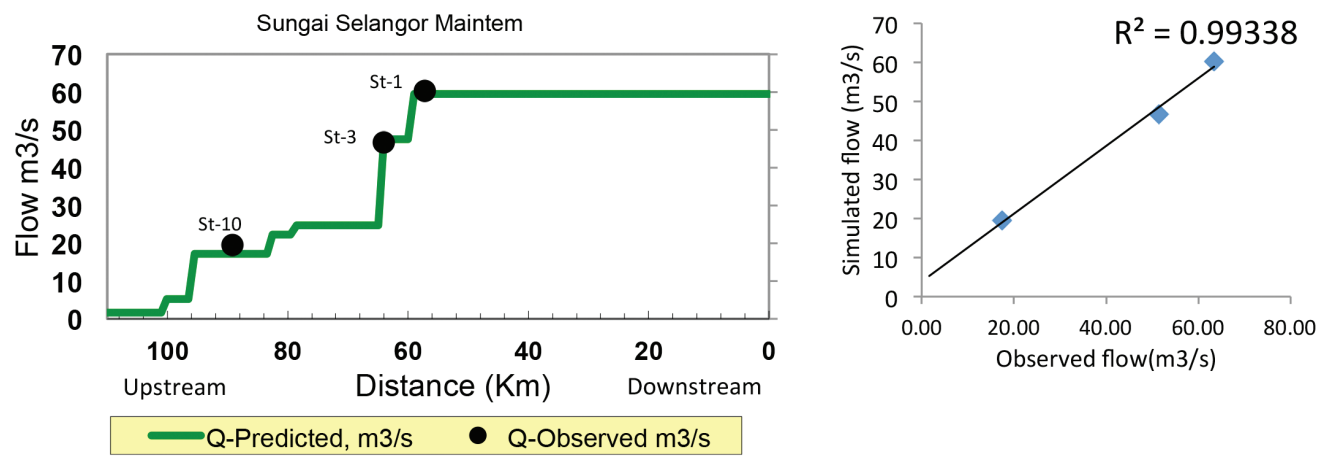

FIGURE 6. Graph of discharge calibration for the main stream of Sungai Selangor 


\section{CALIBRATION OF WATER QUALITY PARAMETERS}

Figure 7 presents the calibration results of DO concentration level along Sungai Selangor. The observed DO pattern is comparable to that of the simulated DO upstream and downstream of the river. The correlation between the observed and simulated DO $\left(\mathrm{R}^{2}\right)$, as per Figure 7 is 0.517 . Henriksen et al. (2003) indicate that this correlation value is deemed good. The model seems to have overestimating the DO values near station St-3. Such errors in this DO modeling are unavoidable because the fieldwork involved gathering a water sample at each monitoring point. Nevertheless, the simulation results were acceptable to realize water environmental management targets under the conditions of limited data (Zhang et al. 2012). The DO concentration level shows decreasing trend towards upstream to downstream. There are three remarkable observations of DO decrease can be seen from Figure 7, the first decrease was at the confluence of Sungai Batang Kali and Sungai Selangor, secondly at the confluence of Sungai Buloh and Sungai Selangor and finally the third decrease at the confluence of Sungai Sembah and Sungai Selangor. The lowest decrease was at the confluence of Sungai Sambah and Sungai Selangor. The DO at upstream starts with $6.88 \mathrm{mg} / \mathrm{L}$ and increases to $9.04 \mathrm{mg} / \mathrm{L}$ just before Batang Kali merges into main stream and then drop to $8 \mathrm{mg} / \mathrm{L}$ and it was steady until just before Sungai Buloh enter into main stream and a small drop $7.89 \mathrm{mg} / \mathrm{L}$. Thereafter, a significant drop of DO was noticed at the confluence of Sungai Sembah and Sungai Selangor. The point that sharply decreases of DO is the point where Sungai Sembah (Rawang sun basin) meet the Sungai Selangor. Downstream of this junction, the DO level becomes around $2.5 \mathrm{mg} / \mathrm{L}$, i.e. at the threshold level of Class IV.

Figure 7 shows the calibration results of the BOD and where the correlation between the observed and simulated BOD $\left(\mathrm{R}^{2}\right)$ found 0.82 . This correlation coefficient fall in the category of very good according to (Henriksen et al. 2003). The level of BOD shows an increasing trend as the river flows downstream. First increase of $1.54 \mathrm{mg} / \mathrm{L}$ of BOD stated at the confluence of Sungai Batang Kali and Sungai Selangor and another slight $1.01 \mathrm{mg} / \mathrm{L}$ increment observed at the confluence of Sungai Buloh and Sungai Selangor and finally $6.97 \mathrm{mg} / \mathrm{L}$ of BOD at the confluence of Sungai Sembah and Sungai Selangor. The highest simulated value of $10.48 \mathrm{mg} / \mathrm{L}$ BOD along the Sungai Selangor was at the point where Sungai Sembah (Rawang sub basin) merge into the Sungai Selangor. Such high BOD at the confluence of Sungai Selangor and Sungai Sembah was due to the contribution of point sources located at Rawang sub basin. Although similar pattern can be seen between the modelled and observed values, the model seems to overestimate the BOD values at St-1. BOD level falls under class III and class IV at the downstream.

The calibration results of the $\mathrm{NH}_{3}-\mathrm{N}$ level are presented in Figure 7. The agreement between the modelled and observed $\mathrm{NH}_{3}-\mathrm{N}$ is generally very good as the correlation between the observed and simulated $\mathrm{NH}_{3}-\mathrm{N}\left(\mathrm{R}^{2}\right)$ is 0.8321 can be seen from Figure 7. This correlation coefficient fall the category of very good according to (Henriksen et al. 2003). The highest concentration of $\mathrm{NH}_{3}-\mathrm{N}$ predicted by the model is around $1.58 \mathrm{mg} / \mathrm{L}$ at the confluence of Sungai Selangor and Sungai Sembah. The sudden rise of $\mathrm{NH}_{3}-\mathrm{N}$ level in downstream of this junction was predicted by the model. The main reason for this abrupt increase in $\mathrm{NH}_{3}-\mathrm{N}$ level can be due to higher ammonia content from the Rawang sub-basin flow, plus the compensation of SOD in the DO model calibration.

\section{PREDICTIVE SCENARIO MODELING}

It can be observed from the calibration results, the model exhibits reasonable agreement against the observed values, although some disagreements are present. Three water quality parameters i.e. DO, BOD and $\mathrm{NH}_{3}-\mathrm{N}$ modelled where DO showed a significant decrease at the confluence of Sungai Sembah and Sungai Selangor while BOD and $\mathrm{NH}_{3}-\mathrm{N}$ showed significant increase at the same point which clearly indicates that Rawang sub-basin is the major contributor to the degradation of the Sungai Selangor basin water quality. Rawang Model predicted an extremely high BOD which enters into main stream of Sungai Selangor through Sungai Sembah, this impact of BOD was observed in Sungai Selangor basin model. Although several types of point sources are located along the Sungai Selangor basin, only three types are spread along each reach of the river network, i.e. STP, Industry and wet market. STPs are the dominant point sources of pollution especially at Rawang sub basin. So a control of point sources at Rawang sub basin possible makes a significant decrease of BOD and $\mathrm{NH}_{3}-\mathrm{N}$ while increase in DO.

\section{IMPACT OF DIFFERENT SCENARIOS ON DO}

It can be observed from Figure 8 that DO at the upstream of the Sungai Selangor falls within class II category and at the downstream start from the confluence of Sungai Sembah and Sungai Selangor falls under class III. The DO results for the five scenarios did not differ very much, however in the Rawang Sub basin the impact of scenario-II causes highest increase of the DO among the scenarios. The increase of DO due to different scenarios simulation are summarized in Table 6 . The maximum increase of DO was $21.6 \%$ at the downstream of Sungai Selangor due to scenario SC-2. In the simulation of SC-2, the point sources load reduction rate was obtained by a trial and error basis such that the water quality at the end of Rawang Sub-basin reached the class-II. The results showed that the pollution load of point sources needed to be reduced by $80 \%$ for DO concentrations to meet the class-II standard at the downstream of Rawang Sub-basin and the Sungai Selangor.

\section{IMPACT OF DIFFERENT SCENARIOS ON BOD}

The variations of BOD due to different scenarios are presented in Figure 9 and the decreased in present of BOD 

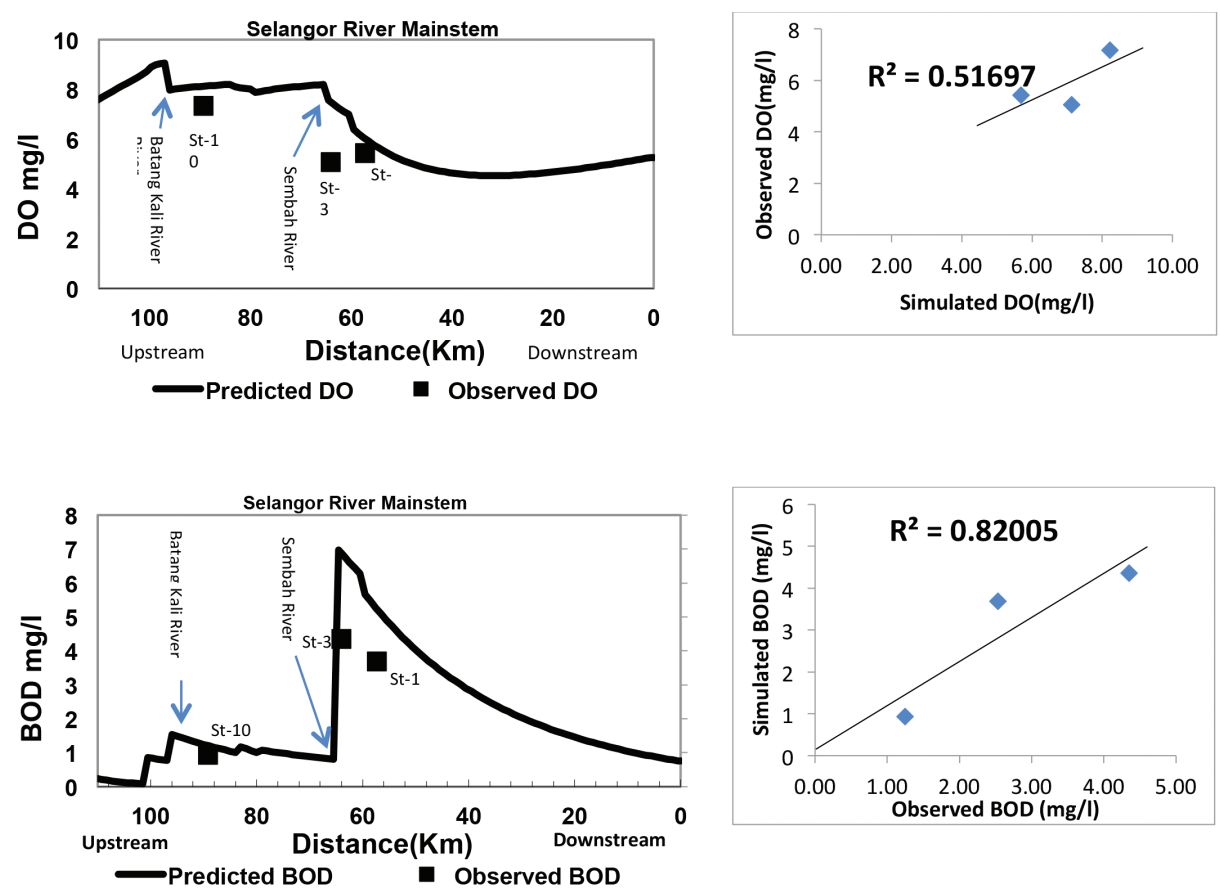

Predicted BOD
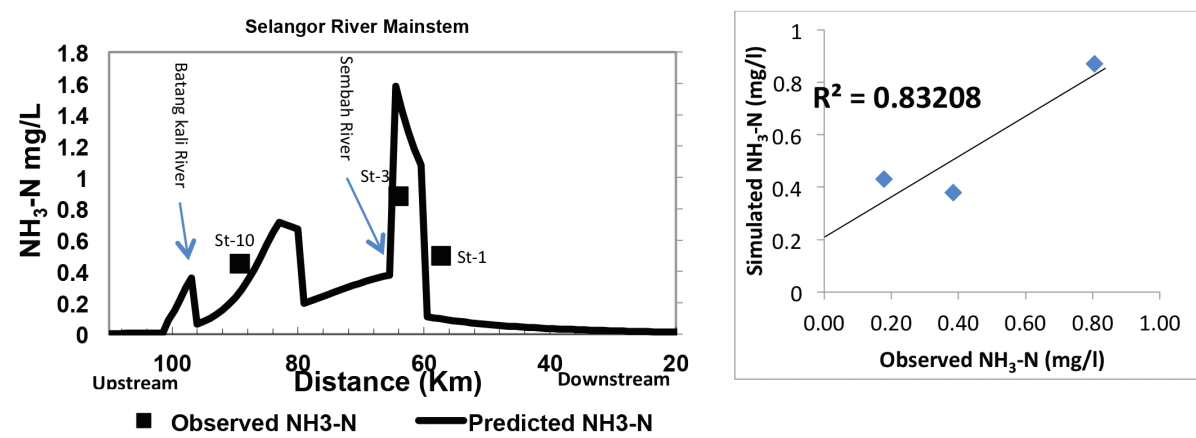

- Observed NH3-N $\longrightarrow$ Predicted NH3-N

FIGURE 7. Calibration of the water quality parameters

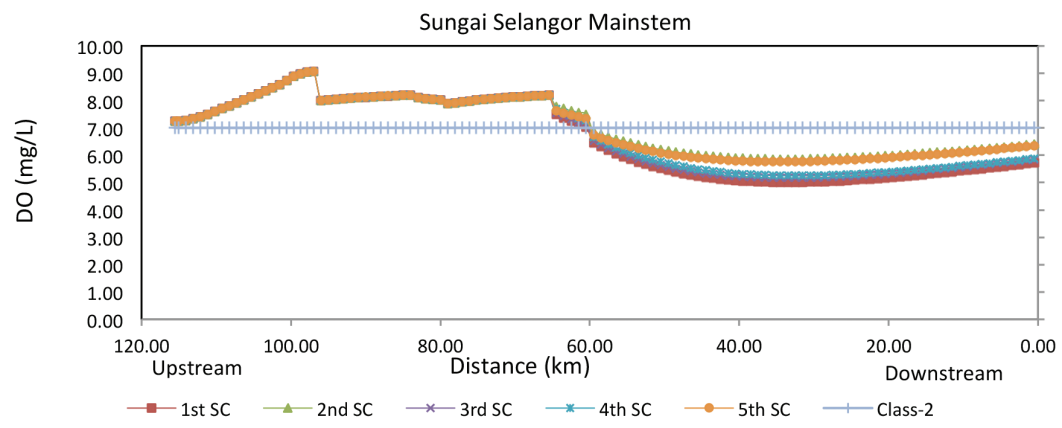

FIGURE 8. Variation of DO along the Sungai Selangor

are shown in Table 6. At the upstream of Sungai Selangor BOD was under class II. The BOD at the confluence of Sungai Selangor and Sungai Sembah fell under class III. The BOD results for the scenarios SC-1,2,3 and 4 did not differ very much but a substantial reduction of BOD values can be seen when Scenarios SC-5 is employed. Although BOD achieved class-II at the downstream of Sungai Selangor due to all scenarios but the maximum reduction of BOD $51.10 \%$ at the downstream of Sungai Selangor due to SC-5. 


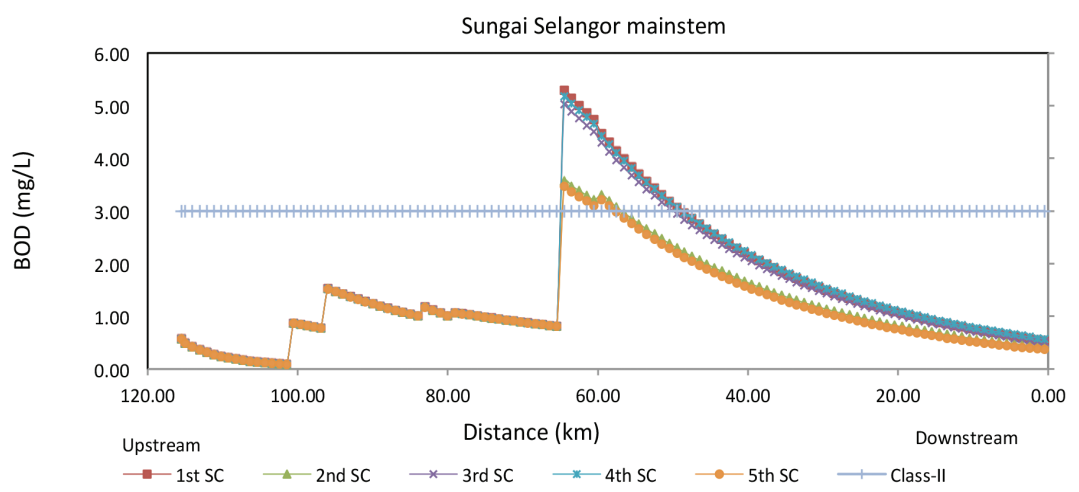

FIGURE 9. Variation of BOD along the Sungai Selangor

\section{IMPACT OF DIFFERENT SCENARIOS ON $\mathrm{NH}_{3}-\mathrm{N}$}

Variation of $\mathrm{NH}_{3}-\mathrm{N}$ at Sungai Selangor due to different scenarios is shown in Figure 10. The $\mathrm{NH}_{3}-\mathrm{N}$ level was extremely high at the confluence of Sungai Selangor and Sungai Sembah. It can be seen from the figures that substantial reduction of $\mathrm{NH}_{3}-\mathrm{N}$ at the confluence of Sungai Selangor and Sungai Sembah can be possible if scenario SC-5 is employed. The level of AN drops from 1.80 to 0.7 $\mathrm{mg} / \mathrm{L}$ at the confluence of Sungai Selangor and Sungai Sembah when SC-5 is employed. It can be seen from Table $6 \mathrm{NH}_{3}-\mathrm{N}$ decrease $66.18 \%$ at the downstream of Sungai Selangor due to SC-5. The decreased of $\mathrm{NH}_{3}-\mathrm{N}$ at Rawang sub-basin leads to the reduction of this parameter at the confluence of Sungai Sembah and Sungai Selangor.

\section{IMPROVEMENT MEASURES OF WATER QUALITY PARAMETERS}

Table 6 summarises the improvement measures of DO, BOD and $\mathrm{NH}_{3}-\mathrm{N}$ at the downstream of the Sungai Selangor. From the simulation, the effect of different scenarios on the DO, BOD and $\mathrm{NH}_{3}-\mathrm{N}$ levels can be seen, especially in Rawang sub-basin. SC-1 investigated whether the point sources within the Rawang sub basin have an effective role on the water quality of Sungai Selangor main stem, where all point sources were adjusted to Standard A. The results showed an improvement in the water quality in terms of DO, BOD and $\mathrm{NH}_{3}-\mathrm{N}$. Due to simulation of SC1 , there was an increase of $8.7 \%$ of DO while BOD and
$\mathrm{NH}_{3}-\mathrm{N}$ decreased to $29.5 \%$ and $20.3 \%$, respectively, at the downstream reach-13 of Sungai Selangor. Due to simulation of scenario SC-1, DO came under class-II at the downstream reach-13 of Sungai Selangor but BOD and $\mathrm{NH}_{3}-\mathrm{N}$ was in class-III. The impact of SC-2 was an increase of DO to $21.5 \%$ while BOD and $\mathrm{NH}_{3}-\mathrm{N}$ decreased $45.20 \%$ and $38.82 \%$, respectively, at the downstream reach-13 of Sungai Selangor. Point sources reductions of $80 \%$ were required for the BOD concentration to fall under class-II, however, $\mathrm{NH}_{3}-\mathrm{N}$ did not meet the standards with a $100 \%$ point source pollution load reduction. This may be because of non-point source pollutants including domestic sewage and agricultural non-point source pollutants. Therefore, reducing only the point source pollution load did not achieve the desired water quality standards. Due to simulation of SC-3, DO increased to $10.80 \%$ while BOD and $\mathrm{NH}_{3}-\mathrm{N}$ decreased to $32.6 \%$ and $49.67 \%$, respectively, at the downstream of Sungai Selangor. DO and $\mathrm{NH}_{3}-\mathrm{N}$ improved and came under classII and class-I, respectively, but BOD remained under classIII at downstream of Sungai Selangor. In scenario SC-4, DO increase to $11.70 \%$ while BOD and $\mathrm{NH}_{3}-\mathrm{N}$ decreased to $25.30 \%$ and $45.16 \%$, respectively, at downstream of Sungai Selangor. DO and $\mathrm{NH}_{3}-\mathrm{N}$ improved and came under class-II and class-I, respectively, but BOD was classIII downstream of Sungai Selangor. Due to simulation of SC-5, DO increases to $20.40 \%$ while BOD and $\mathrm{NH}_{3}-\mathrm{N}$ decreased to $51.10 \%$ and $66.18 \%$ at the downstream of

TABLE 6. Improvement of water quality parameters along the Sungai Selangor main stem due to simulation of scenarios

\begin{tabular}{|c|c|c|c|c|c|c|}
\hline \multirow[t]{2}{*}{ Scenarios } & \multicolumn{3}{|c|}{$\begin{array}{l}\text { Downstream of Sungai Selangor } \\
\text { (Changes in percentage) }\end{array}$} & \multicolumn{3}{|c|}{$\begin{array}{l}\text { Downstream of Sungai Selangor } \\
\text { (Class of water quality parameters) }\end{array}$} \\
\hline & DO & BOD & $\mathrm{NH}_{3}-\mathrm{N}$ & DO & BOD & $\mathrm{NH}_{3}-\mathrm{N}$ \\
\hline SC-1 & $8.7 \%$ & $-29.5 \%$ & $-20.3 \%$ & Class-II & Class-III & Class-III \\
\hline SC-2 & $21.5 \%$ & $-45.2 \%$ & $-38.82 \%$ & Class-II & Class-II & Class-III \\
\hline $\mathrm{SC}-3$ & $10.6 \%$ & $-32.6 \%$ & $-49.67 \%$ & Class-II & Class-III & Class-I \\
\hline SC-4 & $11.7 \%$ & $-25.3 \%$ & $-45.16 \%$ & Class-II & Class-III & Class-I \\
\hline $\mathrm{SC}-5$ & $20.40 \%$ & $-51.10 \%$ & $-66.18 \%$ & Class-II & Class-II & Class-I \\
\hline
\end{tabular}




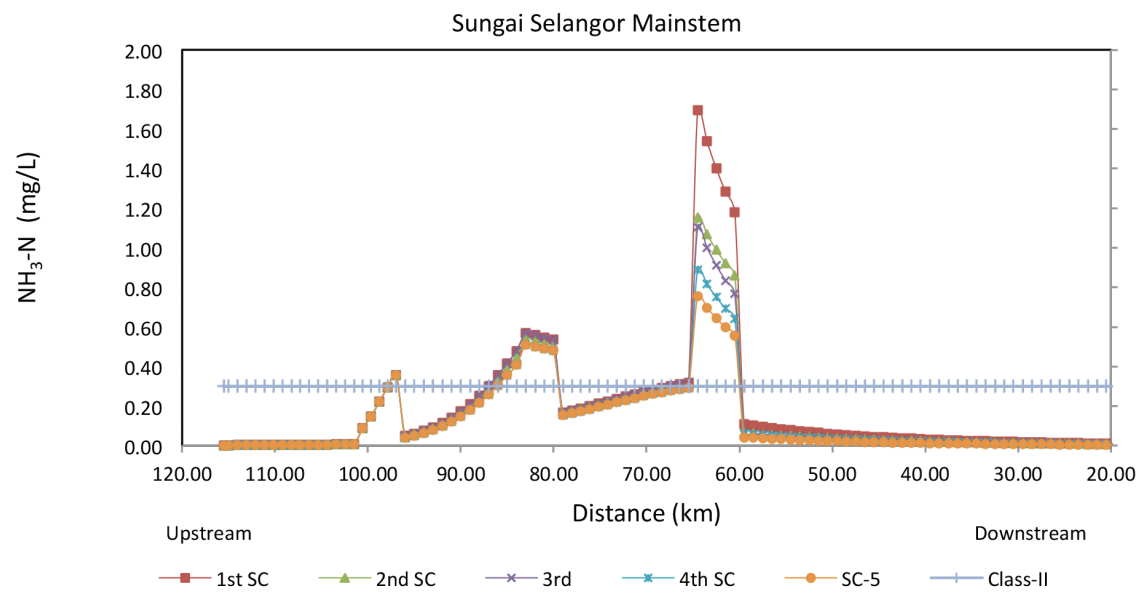

FIGURE 10. Variation of $\mathrm{NH}_{3}-\mathrm{N}$ along the Sungai Selangor

Sungai Selangor. The highest performance of pollutants reduction was achieved by $\mathrm{SC}-5$. DO, BOD and $\mathrm{NH}_{3}-\mathrm{N}$ improved and came under class-II, class-II and class-I, respectively, downstream of Sungai Selangor. Thus, SC-5 is the most effective for water quality improvement in comparison to other scenarios.

\section{CONCLUSION}

In this study, investigation of water quality status of Sungai Selangor basin has been implemented to enhance the understanding of current water pollution status of the river basin, and water quality results have been included in QUAL2K modelling process to improvement measure of the DO, BOD and $\mathrm{NH}_{3}-\mathrm{N}$. The water quality of Sungai Selangor varies from the upstream to the downstream region, and it also depends on the land use pattern. Sampling stations located at the upstream and middle stream are registered classes II and III, while in Rawang sub basin the water quality falls in class-IV based on the NWQS for Malaysian rivers. This indicates that pollution level in the Rawang sub basin is relatively high for some water quality parameters. The worst situation as per as water quality is concerned, was observed at Rawang sub basin compared to other sub- basins. The simulations included in this study were designed to provide information on present and future status of Sungai Selangor basin. The changes of Selangor water quality due to the introduction of different scenarios have also been presented. From the simulation, the effect of different scenarios in the BOD and $\mathrm{NH}_{3}-\mathrm{N}$ can be seen, especially in Rawang sub-basin. A substantial reduction of $\mathrm{NH}_{3}-\mathrm{N}$ and BOD level has been predicted by the model after the implementation of scenarios SC- 2 and SC-5. The simulation also showed that $51.10 \%$ and $66.18 \%$ reduced level of BOD and $\mathrm{NH}_{3}-\mathrm{N}$, respectively, can be obtained if scenario SC-5 is employed. Immediate actions, addressing river water quality problems in the Rawang sub-basin is deemed crucial for substantially enhancement of the subbasin and downstream areas of Sungai Selangor. Water quality model provides a clear understanding of control of point sources to maintain a reasonable water quality class at the downstream of Sungai Selangor. This will assist decision makers to identify the spatial levels and reasons for water quality problems, such as land use practices and their effects on Sungai Selangor basin. Furthermore, the outcomes of the research can provide a benchmark level to be used in the exploration of strategies to protect human health and the ecosystem and an environmental reference for water pollution control of Sungai Selangor basin. Continuous monitoring, proper planning and control on human activities are recommended to ensure that developments within the watershed do not contribute to the degradation of Sungai Selangor water quality. It is recommended that the future research work will focus the performance evaluation criteria for this model using root mean square error or mean absolute error or NashSutcliffe index with more data set. Some key water quality parameters such as nitrogen and phosphorus was not considered in this study so analysis of these water quality parameters is recommended for further study.

\section{ACKNOWLEDGEMENTS}

The authors highly appreciate the financial support of University Malaya Research Grants (FL026-2012D, FL001-13SUS and RP017C-15SUS). We would also like to acknowledge the support given by the Ministry of Education (MOE), Malaysia and JSPS Asian CORE Program.

\section{REFERENCES}

APHA. 2003. Standard Methods for the Examination of Wastewater. Washington, DC, USA: America Public Health Association.

Bordalo, A.A., Teixeira, R. \& Wiebe, W.J. 2006. A water quality index applied to an international shared river basin: The case of the Douro River. Environmental Management 38: 910-920. doi: 10.1007/s00267-004-0037-6.

Bottino, F., Ive, C.F., Eduardo, M.M. \& Maria, d.C.C. 2010. Calibration of QUAL2K model in Brazilian micro watershed: Effects of the land use on water quality. Acta Limnologica Brasiliensia 22(4): 474-485. 
Brown, L.C. \& Barnwell, T.O. 1987. The Enhanced Stream Water Quality Models QUAL2E and QUAL2E-UNCAS. U.S. Athens, GA: Environmental Protection Agency.

Chapra, S.C., Pelletier, G.J. \& Tao, H. 2008. QUAL2K: A Modeling Framework for Simulating River and Stream Water Quality. Tufts University: Medford, OR.

Cho, J.H. \& Sung, R.H. 2010. Parameter optimization of the QUAL2K model for a multiple-reach river using an influence coefficient algorithm. Science of the Total Environment 408(8): 1985-1991.

Dhanalekshmy, T.G., Rajani, V. \& Bhaskar, M. 2014. Water quality analysis of two surface water resources in Thiruvananthapuram, India. Res. J. Chem. Environ. 18(7).

DOE. 2009. Malaysia Environmental Quality Report 2009. Kuala Lumpur, Malaysia: Department of Environment (DOE), Ministry of Natural Resources and Environment.

Dylan, U. 2016. Application of Qual2k model to macrophyte rich silver bow creek. Master of Science in Environmental Engineering, Environmental Engineering, Montana Tech of the University of Montana (Unpublished).

Fan, C., Chun-Han, K. \& Wei-Shen, W. 2009. An innovative modeling approach using Qual2K and HEC-RAS integration to assess the impact of tidal effect on River Water quality simulation. Journal of Environmental Management 90(5): 1824-1832.

Gardner, K.K. \& Brian, L.M. 2009. Seasonality in spatial variability and influence of land use/land cover and watershed characteristics on stream water nitrate concentrations in a developing watershed in the Rocky Mountain West. Water Resources Research 45: W08411. doi:10.1029/2008WR007029.

Hema, S. \& Subramani, T. 2013. Study of physico-chemical characteristics of surface water using regression analysis of Cauvery River and its tributaries in Tamilnadu, India. Asian Journal of Chemistry 25(6): 3199-3203.

Henriksen, H.J., Lars, T., Nyegaard, P., Torben, O.S., Jens, C.R. \& Bjarne, M. 2003. Methodology for construction, calibration and validation of a national hydrological model for Denmark. Journal of Hydrology 280: 52-71.

Ibrahim, M., Faridah, O., Adriana, I.N.I., Alaa-Eldin, M.E. \& Rossita, M.Y. 2015. Assessment of water quality parameters using multivariate analysis for Klang River basin, Malaysia. Environmental Monitoring and Assessment 187(1): 1-12.

Kannel, P.R., Lee, S., Lee, Y.S., Kanel, S.R. \& Pelletier, G.J. 2007. Application of automated QUAL2Kw for water quality modeling and management in the Bagmati River, Nepal. Ecological Modelling 202(3): 503-517.

Kim, S., Young-Ki, P., Chan-Hee, W. \& Min-Hwan, K. 2016. Analysis of scenarios for environmental instream flow considering water quality in Saemangeum Watershed. $J$. Korean Soc. Environ.Eng. 38(3): 117-127. doi: org/10.4491/ KSEE.2016.38.3.117

Malaysia's and Climate. 2016. Malaysian Meteorological Department. http://www.met.gov.my/en/web/metmalaysia/ climate/generalinformation/malaysia.

Marzouni, M.B.,Ali, M.A., Hadi, M., Nematollah, J., Javad, A. \& Houshang, H. 2014. Evaluation of Karun River water quality scenarios using simulation model results. International Journal of Advanced Biological and Biomedical Research 2(2): 339-358.

Moalla, M.A., Mirsanjari, M.M. \& Zarekar, A. 2013. The necessity of examining aquatic recipient environments of waste waters in water resources environmental management utilizing simulating model QUAL2K. Global Journal of Medicinal Plant Research 1: 157-165.

Park, S.S. \& Yong, S.L. 2002. A water quality modeling study of the Nakdong River, Korea. Ecological Modelling 152(1): 65-75.

Paul, M.J. \& Judy, L.M. 2008. Streams in the urban landscape. Urban Ecology 32: 333-365.

Seyam, M. \& Faridah, O. 2015. Long-term variation analysis of a tropical river's annual streamflow regime over a 50-year period. Theoretical and Applied Climatology 121: 71-85. doi: 10.1007/s00704-014-1225-9.

Sánchez, E., Colmenarejo, M.F., Vicente, J., Rubio, A., Maria, G.G., Travieso,L.\& Rafael, B. 2006. Use of the water quality index and dissolved oxygen deficit as simple indicators of watersheds pollution. Ecological Indicators 7(2): 315-328. doi: 10.1016/j.ecolind.2006.02.005.

Subramaniam, V. 2004. Managing Water Supply in Selangor and Kuala Lumpur. Buletin Ingenieur 22: 12-20.

Sunusi, I., Yusuf, A.A. \& Gaurav, S. 2016. Assessment of surface water quality using Qual2k software: A case study of River Yamuna, India. European Journal of Advances in Engineering and Technology 3(7): 16-23.

Suratman, S. \& Norhayati, M.T. 2013. Kesan antropogenik terhadap kualiti air di lembangan Sungai Marang, Perairan Selatan Laut China Selatan. Sains Malaysiana 42(6): $743-$ 751.

Teck, Y.L., Nyanti, L., Muan, T., Jongkar, G., Fong, S.S. \& Aazani, Md. 2016. Physicochemical parameters of bakun reservoir in Belaga, Sarawak, Malaysia, 13 months after reaching full supply level. Sains Malaysiana 45(2): 157-166.

Tetra Tech, Inc. 2009. New River QUAL2K Water Quality Model for the New River Dissolved Oxygen TMDL. San Francisco, California United States Environmental Protection Agency Region 9.

Vasudevan, M., Nambi, I.M. \& Suresh, K.G. 2011. Application of QUAL2K for assessing waste loading senario in river yamuna. International Journal of Advanced Engineering Technology 2(2): 336-344.

Wang, C., Cyterski, M., Feng, Y., Gao, P. \& Sun, Q. 2015. Spatiotemporal characteristics of organic contaminant concentrations and ecological risk assessment in the Songhua River, China. Environ. Sci.: Processes Impacts 17(11): 1967-1975.

Zainudin, Z., Rahman, N.A., Abdullah, N. \& Mazlan, N.F. 2010. Development of water quality model for Sungai Tebrau using QUAL2K. Journal of Applied Sciences 10(21): 2748-2750.

Zhang, R., Xin, Q., Huiming, L., Xingcheng, Y. \& Rui, Y. 2012. Selection of optimal river water quality improvement programs using QUAL2K: A case study of Taihu Lake Basin, China. Science of the Total Environment 431: 278-285.

Zhang, R., Xin, Q., Wenting, Z., Hailong, G., Wei, H. \& Jinhua, W. 2014. Simulation and evaluation of pollution load reduction scenarios for water environmental management: A case study of inflow river of Taihu Lake, China. International Journal of Environmental Research and Public Health 11(9): 9306-9324.

Zhang, Y., Huige, Y. \& Zhisong, W. 2016. Simulating water quality of Wei River with QUAL2K model, a case study of Hai River Basin in China. MATEC Web of Conferences. 
Civil Engineering Department

Faculty of Engineering

University of Malaya

50603 Kuala Lumpur, Federal Territory

Malaysia
*Corresponding author; email: faridahothman@um.edu.my

Received: 1 June 2017

Accepted: 8 September 2017 